\title{
当院での全腹腔鏡下子宮全摘術における試み
}

\author{
国立病院機構 京都医療センター
}

宇治田麻里、住友理浩、高倉賢人、川村洋介、高倉賢二、小西郁生

\section{An attempt to simplify total laparoscopic hysterectomy procedures at our hospital}

\author{
Mari Ujita, Masahiro Sumitomo, Masahito Takakura, \\ Yosuke Kawamura, Kenji Takakura, Ikuo Konishi \\ Department of Obstetrics and Gynecology, National Hospital Organization Kyoto Medical center
}

\begin{abstract}
Objective: We are currently testing a simplified and safe laparoscopic hysterectomy procedure in our clinical practice that is technically similar to laparotomy. The present study aimed to evaluate the feasibility of this modified total laparoscopic hysterectomy (TLH) method, which uses the RUMI II Colpotomiser System and without requiring separation of the ureter and uterine artery for laparoscopic surgeons under training.

Methods: During the procedure, uterine vessels and ureters are not skeletonized, the vaginal vault is identified using a colpotomy cup, and retrograde dissection is performed from the anterior vaginal wall. We used statistical analysis to evaluate operative time, parity, body mass index (BMI), blood loss, and surgery-related complications by Student's $t$-test.

Results: We have performed 11 TLH procedures applying the above method, excluding cases of severe adhesion, since 2016. Compared with the traditional TLH method, average operating time was significantly shorter using the new method. There was no significant difference between the two groups with regards to parity, BMI, or blood loss. No complications have occurred postoperatively since 2016; whereas, one vesicovaginal fistula occurred in the 18 TLH performed before 2016 .

Conclusion: This simplified TLH procedure may be a safe and effective alternative for laparoscopic beginners as it is similar to that of abdominal hysterectomy. Furthermore, the exclusion of complicated tissue peeling reduces operator stress and surgery-related complications.
\end{abstract}

Key words: laparoscopic hysterectomy, complication

\section{概 要}

当院では、全腹腔鏡下子宮全摘術（TLH）は 腹式子宮全摘術（TAH）を腹腔鏡下に再現した ものである、という概念に基づき、TLHの改良 を行ってきた。腹腔鏡下でも開腹手術に近い方法 で手術を行うことにより、簡潔でわかりやすく安 全性の高い手術を実践しているため紹介する。

\section{はじめに}

TLHはTAHと比して侵襲が少なく入院期間が
短縮する、傷が小さく術後疼痛が軽減する、など のメリットが得られる反面、腹腔鏡特有の問題と して開腹手術と比較して視野が限定されること、 触診が不可能であるため臟器オリエンテーション が困難、子宮の牽引力に限界がある、という問題 があり、膀胱損傷や尿管損傷などの合併症にはよ り注意をはらう必要があるとされている1)。

TAHでは、尿管を触診でその走行を確認でき ること、及び子宮を強く頭側に牽引することで尿 管の走行位置が相対的に外側に偏倚するため、尿 管合併症を予防することが可能となる。また子宮 
頝部を触診で確認することで、腟円蓋及び傍胵組 織の切開ラインを把握することが容易となる。こ れに対してTLHにおいては、鉗子で子宮を把持・ 操作することでは子宮の牽引が十分に行えず、尿 管が外側に十分偏倚しないため、尿管合併症を避 けるためには開腹手術とは異なるアプローチが必 要とされている ${ }^{2.3)}$ 。具体的には、尿管及び子宮動 脈を広間膜腔から剥離し、直視下にその走行を確 認する方法が多く用いられている。しかし，腹腔 鏡初学者にとっては、広間膜腔を展開しその中の 尿管及び子宮動脈の走行を直視下に確認するとい う方法は、浅子宮静脈の損傷など思わ出血をき たす恐れがあり、困難を伴う ${ }^{4)}$ 。また広間膜腔の 出血を不用意に止血することで尿管合併症などの 可能性も危惧される。

近年では、子宮の牽引に着目した内視鏡補助器 具が開発され多くの施設で普及している。当院で も2016年 4 月よりルミ II コルポトマイザーシステ ム（ケン・メディカル、日本）を導入し、TLH での安全性向上、簡素化㧍よび手術時間の短縮に 役立てている。

ルミ II コルポトマイザーシステムはディリニエ イターカップとニューモオクルーダー、ハンドル 部分よりなる腹腔鏡下臸壁切開システムである (図 1)。ディリニエイターカップ（以下カップ） で子宮䅡部を覆うようにカップを腟内に留置する と、カップの辺縁が腟円蓋部に留置され、これを 強く腹腔内側に挙上することで胵円蓋部の位置が 腹腔内側からも明瞭に確認可能となるシステムで ある。

以下に当院で行っているTLHの詳細を記す。

\section{方 法}

(1)半載石位で手術を開始する。トロッカーの配 置は臍部に $12 \mathrm{~mm}$ のカメラポート、鉗子用として 左右側腹部、恥骨上正中に $5 \mathrm{~mm}$ の計 4 カ所とす
るダイヤモンド型の配置を用いている。

カップをあらかじめ腟内に挿入しておく。カッ プは $3.0 \mathrm{~cm}, 3.5 \mathrm{~cm}, 4.0 \mathrm{~cm}$ の 3 サイズがあり、腟腔 の広さと子宮䅡部の大きさに合わせて選択する。 カップ留置後にハンドル部分を装着し、ニューモ オクルーダーを胵腔内で拡張しておく。

気腹開始後は約15度の骨盤高位にして手術を行 う。

(2)子宮は腸鉗子などで円勒帯や卵巣固有勒帯を 把持牽引しつつ、円勒带を Advanced Bipolar System（ABS）で凝固切断後、monopolarを用 いて膀胱子宮窩腹膜の切開を行う。

(3)尿管の走行の確認を行う（図 2)。原則的に 尿管及び子宮動脈の露出は行わず、後腹膜から透 見し、走行を確認するのみに留める。

(4)卵巣固有勒帯と卵管の切断を行い、仙骨子宮 勒带子宮付着部まで広間膜の切断を行う。この際、 広間膜越しに透見した尿管の走行を確認しながら 広間膜を切開する事により、尿管の損傷を回避す ることができる。

(5)カプを強く腹腔側に挙上する事で子宮毫引 の代わりとなり、膀胱を子宮䅡部から剥離するに 際して剥離ラインが明暸となる。腹腔内側からカ ップに沿って膀胱を鈍的に剥離することにより、 膀胱を安全に剥離することが可能となる。

(6)再度カップを頭側に押し込み、子宮側方の切 開予定ラインを確認する。カップを強く腹腔内側 に挙上することで、尿管は相対的に外側に偏倚す ることとなり、腔側から押し込まれて明暸となっ たカップの辺縁の高さで子宮側方靵帯を切断する ことにより十分安全に子宮側方の処理が可能とな る。側方の切断はABSを用いて処理する（図 3 )。 この際ABSが滑脱しないように子宮頸部に向か ってしっかり押し付けることが必要であると考え ている。あらかじめ切開予定線の組織を結紮して おけばより確実な止血が可能である（図 4)。

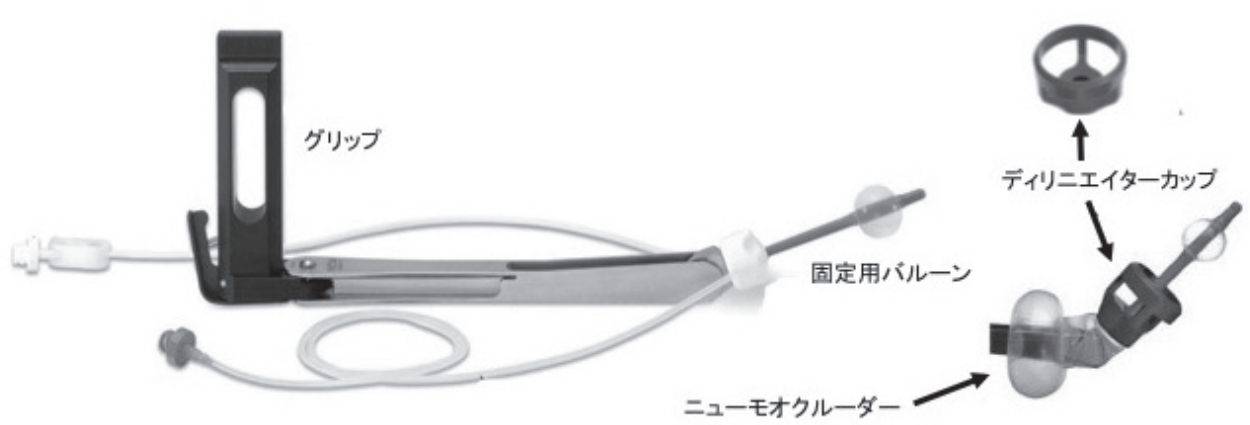

図1 ルミாコルポトマイザーシステム 


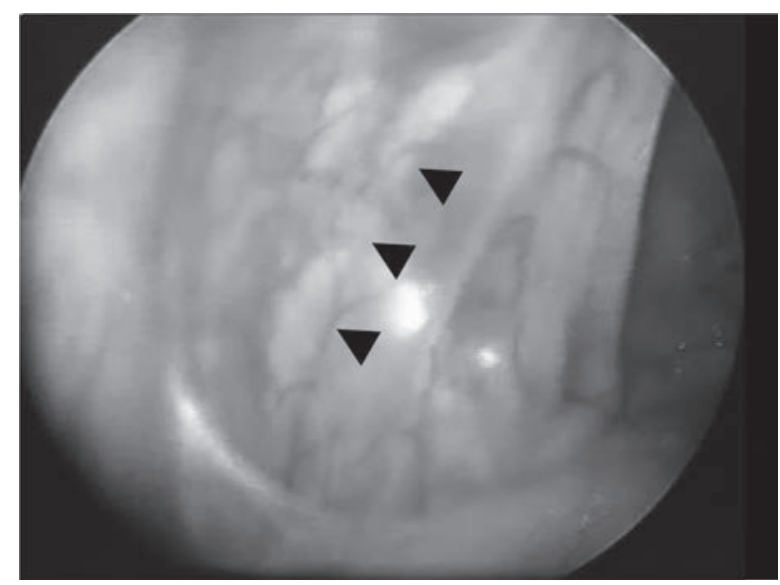

図2 尿管の走行

矢頭は広間膜越しに透見される尿管



図4 子宮側方血管の結禁 矢頭は子宮側方血管 $U t ：$ 子宮体部 Cx : 子宮䫋部

(7)カップを再度強く挙上し、カップの辺縁に沿 ってmonopolarを用いて胵壁の切開を行う。腟管 が解放されてもニューモオクルーダーにより腟が 閉鎖されている為、腹腔内圧が低下することはな い。腟壁を切開した後、子宮腟部をディリニエイ ターカップで押し込み、前胵壁を把持力の強い鉗 子で把持し牽引することで、腟円蓋が腹腔内側か らも明瞭となるため、ABSにて腟壁の切開を全 周に延長する（図 5 )。後腟壁切開時は仙骨子宮 勒帯も一括して切断する。この際も組織が厚いた め滑脱への注意が必要で、ABSを押し付けるよ うにして処理する。

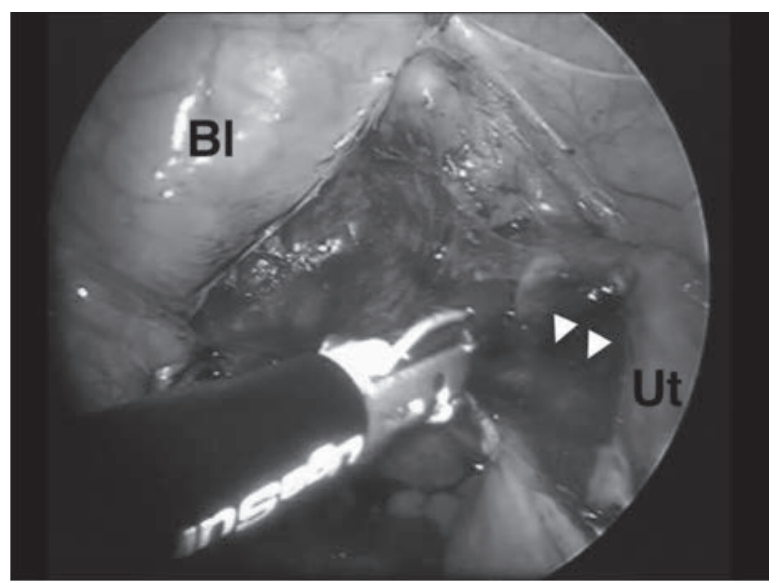

図3 子宮側方血管の処理 矢頭は子宮動脈 $U t$ ：子宮体部 $\mathrm{BI}$ ：膀胱

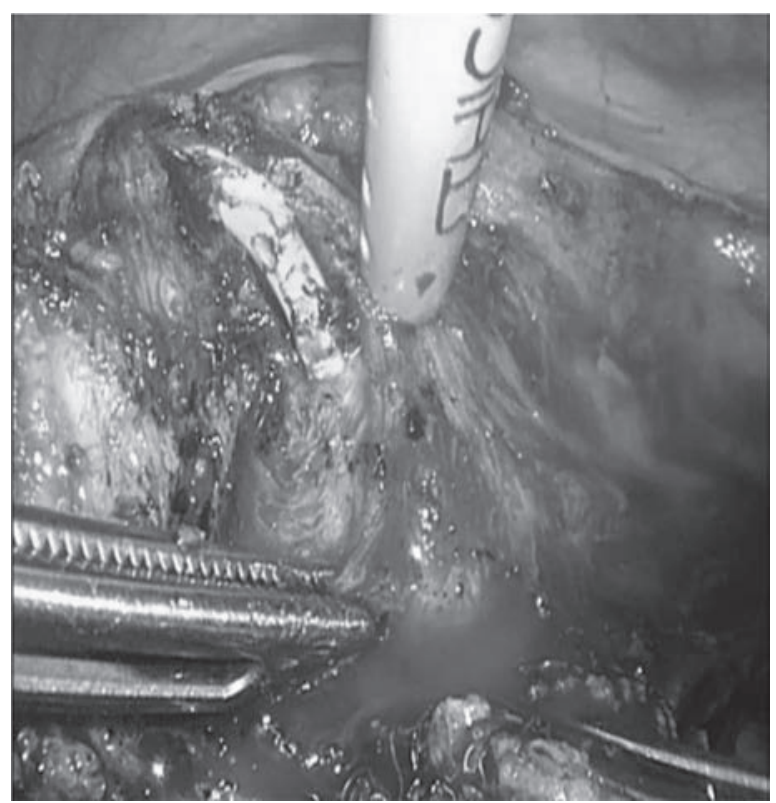

図 5 胵壁の切開

8)切離した子宮は腟腔より体外に摘出し、腟断 端は腹腔鏡下に 0 バイクリル糸を用いて両側端を 結節縫合し、その間をZ縫合で数回縫合閉鎖し、 腟側からガスの漏出がないことを確認し、ポート 孔を縫合閉鎖し手術を終了する。

本術式の有用性を検討するために各症例の手術 時間、経産回数、BMI、出血量、子宮重量につい て統計学的に解析を行い、これまで当院で行って いたTLHとの比較を行った。

検討には検定を用い、 $\mathrm{p}<0.05$ を有意差ありと した。 


\section{適応}

当科では、本術式によるTLHは主に子宮筋腫、 子宮腺筋症などの子宮良性疾患やCervical Intraepithelial Neoplasia（CIN）を主な対象とし ている。CINの際、切除断端が陽性とならないよ うにするために、カップ装着前に子宮䅡部をルゴ ール液にて染色し、不染領域の外側に縫合糸で4 カ所結紮を行い、胵壁切開時に目印となるように している。

子宮の大きさについては明確な規定は設けてい ないが、手拳大までをTLHの上限の目安として いる。それ以上の大きさになると子宮の可動性が 制限され把持が難しく、カメラの視野確保も困難 となるため、腹腔鏡操作の難易度が高くなり出血 量も多くなる傾向にあるためである。子宮澒部筋 腫はカップによる腟壁切開ラインの同定が困難で あること、傍子宮組織の血流増加により腟壁切開 時に止血困難となる恐れがあることから適応外と している。

\section{成 績}

当院では2016年度よりルミII コルポトマイザー システムを導入しこれまで11症例において上述の 方法でTLHを完逐した。全例内視鏡技術認定医 資格を未取得の医師による執刀であった。子宮腫 大が著明で把持が困難な例や子宮頸部付近に子宮 筋腫のある症例、癒着症例などは手術時間が長引 くと予想され最初からTLHの適応とはせず、原 則LH, LAVHとした。2016年度以降のTLHの平均 手術時間は161分であった。これに対し、2014年度、 2015年度のTLH18例の平均手術時間は194分（認 定医による手術13例の平均時間191分、認定医以 外による手術 4 例の平均時間204分）であり現法 でのTLHでの手術時間が有意に短縮していた $(\mathrm{P}=0.014$, Student's t-test)。両群間で経産回数 (現 法 : $1.63 \pm 0.2$, 従来法 : $2.1 \pm 0.28$ ) PBMI（20.2 \pm $0.64,22.6 \pm 1.1)$ 、出血量 $(51.4 \pm 13.1,71.2 \pm 20.3)$ 、 子宮重量（146.1 $\pm 20.3,119.5 \pm 22.3 ）$ に差は認め なかった。術中・術後合併症は従来法のTLHで 膀胱腟瘻を 1 例生じたが、2016年以降は認めてい ない。

\section{考察}

TLHは子宮の切離から腟断端の縫合閉鎖まで をすべて腹腔鏡下に行う術式であるため、未経産
婦など腟の狭い症例でも施行可能であり、また腟 式子宮全摘術よりも術後の疼痛が少ないというメ リットもあるため ${ }^{6}$ 、現在多くの施設に普及して いる。

当院では、これまでTLH全例において後腹膜 腔を展開し尿管と子宮動脈本幹の剥離 - 同定、子 宮動脈本幹を処理するという方法を行ってきた が、複雑な手技のため術者が限られることや習熟 するまでは手術時間が長くなるという問題、また TAHとは異なる手順が入ることによる合併症増 加の危惧があった。

2016年度に入り腹腔鏡手術に習熟した医師が大 幅に減少したことをきっかけにルミ II コルポトマ イザーシステムを導入し、初心者でも安全に TLHが完遂できる術式の工夫を行ってきた。術 者はTAHの術式については熟知しているため、 $\mathrm{TAH}$ の腹腔鏡での再現として理解しやすく、最 大の難関である子宮動脈・尿管の剥離操作を行わ ないことでTLHに対する苦手意識を軽減できる。 また手術時間の短縮・慎重な剥離操作の省略によ り後半の腟断端縫合操作まで集中力を維持できる というメリットがある。

腹式手術に近い方法（切断ライン）として、尿 管及び子宮動脈本幹の展開・露出を行わない本術 式に重要な役割を果たすのは腟円蓋の足方からの 圧排とシーリングデバイスの使用である。

カップにて腟側から子宮を強く挙上することに より、腹腔鏡操作のみでは不十分な子宮牽引の代 替法とすることができ、腟円蓋の切開ラインと尿 管及び膀胱の間に距離を作ることが出来るため、 安全に子宮側方組織の切離ができる。また、カッ プを胵壁に向かって強く押し付けることにより腟 壁切開部が明瞭に浮き上がるため、子宮頸部に切 り达むことなく適切な位置で切断することができ $b^{5)}$ 。

腟円蓋部の挙上と切開部の同定は従来腟パイプ (図 7 ) によって行っていたが'、そもそも腟管の 走行は下 $1 / 3$ と上 $2 / 3$ では角度が異なっており ${ }^{7)}$ 、 向きが異なる腟管に一直線のパイプを用いて十分 に円蓋部を挙上することは原理的に困難である。 ルミII コルポトマイザーシステムではカップの辺 縁が臸円蓋全周に留置されており、シャフトとカ ップの方向を変えることができるため、腟パイプ と比べて自在に腟円蓋を挙上することが可能とな る。またマニピュレーターとしての機能もあるた め、子宮の前後屈・左右への可動が得られ子宮側 方の処理や胵壁切開時に有用である。 


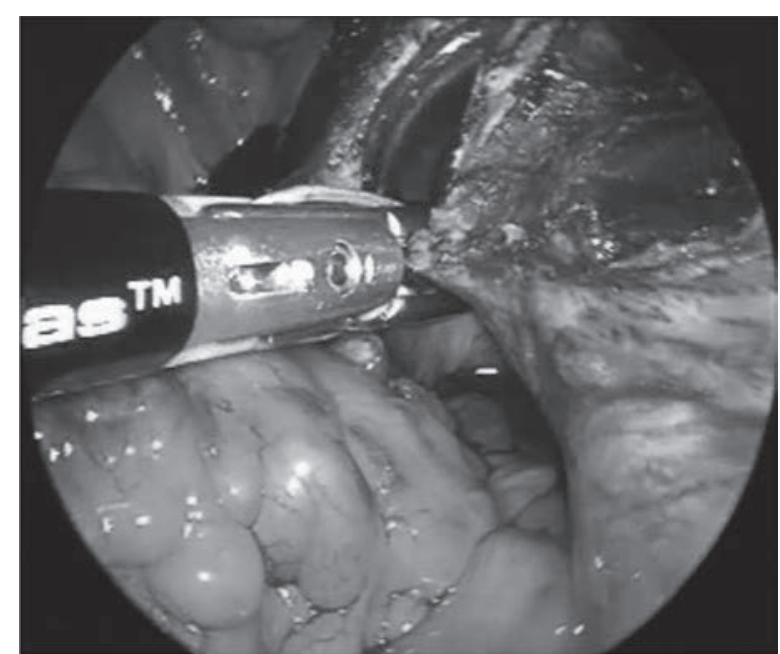

図6ABSによる傍胺組織, 膣壁の切断

広間膜の切開, 前腟壁の切開以外の組織の切断 にはABSを用いているが、優れたシーリング機 能により確実な止血ができ8)、短時間での処理が 可能である。一度のシーリングで十分な効果が得 られるが、子宮動脈など止血を確実にしたい部位 には 2 回のシーリングを実施している。仙骨子宮 勒带などの厚みのある組織に使用する場合には、 滑脱に注意が必要である。傍胵組織を含めた胵壁 の切断もABSで行っているため、胵断端の離開 予防のため術後 3 ケ月間は性交渉の禁止を含む局 所安静を指示しており、これにより現在まで離開 症例は経験していない。ABSはmonopolarと比し て周囲への熱損傷が来しにくいことも特徴の一つ であるが、周囲への熱の伝播が完全に遮断できる わけではないので、膀胱から切断部まではある程 度（約 $5 \mathrm{~mm}$ ) の余裕が必要と考えている。

尿管と子宮動脈の洜離、露出を行わないことで 当院での平均手術時間は 161 分と他施設での報告 と比べ短めであるが、巨大子宮筋腫症例など手術 が困難と思われるものは適応外としていることも 理由の一つとなる。

手術時間の延長、出血量増加、術者へのストレ スなどを考えた場合にそのような症例への腹腔鏡 手術が開腹手術に優る手術とは考えにくいからで ある。特に腹脡鏡初心者にとって、適応症例の選 択を誤らないことが、合併症を減らす最大の要因 かもしれない。

\section{まとめ}

以下に本術式のポイントをまとめる。

(1)ディリニエイターカップを用いて円蓋を挙上 する本術式では、高度の癒着や澒部近くに腫瘤が



図 7 腟パイプ

及ぶ症例を除いて尿管剝離や子宮動脈本幹の処理 は不必要である。

(2)視野確保のため、子宮の牽引方向への配慮が 常に必要である。

本術式では開腹での子宮全摘術を腹腔鏡下に再 現したものであるため、原則的に子宮動脈や尿管 の剥離同定を行わず腹腔鏡の熟練者でなくても容 易に習得でき安全に行える術式である。癒着症例 では従来通りの処理が必要なことは言うまでもな いが、適応を間違わなければ無駄な操作を極力省 くことで合併症発生のリスクを減らし、手術時間 を短縮し、侵襲をより少なくすることが可能と思 われる。今後さらに症例を増やし検討を重ねたい と考えている。

\section{文献}

1) 塩田 充 : わが国における婦人科腹腔鏡下手術の現 況、日本産婦人科学会雑誌、2008；60（4）：11131120

2) 渡邊 まり子、山下 剛、西脇 邦彦、他：当科に おける全腹腔鏡下子宮全摘術（TLH）の工夫、産婦 人科治療、2007；95（3）：309-313.

3 ）安藤 正明、羽田 智則、太田 啓明、他：腹腔鏡 下子宮全摘術における合併症予防のコツ、産科と婦 人科、 $2008 ; 75$ (4) : 472-475.

4 ) 松浦 俊明、児島 信子、濱崎洋一郎、他：初期子 宮動脈結紮を伴う腹腔鏡下子宮全摘術のラーニング カーブに関する検討、産婦人科の実際、2010；59 : 1269-1275.

5 ) L. Mettler, N. Ahmed-Ebbiary and T. Schollmeyer : Laparoscopic hysterectomy: Challenges and limitations. Minimally Invasive Therapy, 2005 ; 14 : 
3 ; 145-159.

6 ) 武本 幹彦、橋本 公、妹尾 大作：自家製腟パイ プを用いた腹腔鏡下子宮全摘出術. 産婦中四国会誌、 2004 ; 53 (1) : 96-100.

7 ) Shirish S Sheth : Vaginal Hysterectomy, 2014 ; 251, Jaypee Brothers Medical Publishers (P) Ltd, India

8 ）濱地 勝弘、横山 幹文、高木香津子、他：当科に おける腹腔鏡下子宮全摘術に関する前方視検討、日 本産科婦人科内視鏡学会誌、2007；23（1）：133137.

投稿日：2017年 6 月 18 日

採択日：2017年10月16日 